\title{
Rapid Assessment of Soil and Groundwater Tritium by Vegetation Sampling (U)
}

by

C. E. Murphy Jr.

Westinghouse Savannah River Company

Savannah River Site

Aiken, South Carolina 29808

DOE Contract No. DE-AC09-89SR18035

This paper was prepared in connection with work done under the above contract number with the U.S.

Department of Energy. By acceptance of this paper, the publisher and/or recipient acknowledges the U.S. Government's right to retain a nonexclusive, royalty-free license in and to any copyright covering this paper, along with the right to reproduce and to authorize others to yeproduce all or part of the copyrighted paper. 


\section{DISCLAIMER}

This report was prepared as an account of work sponsored by an agency of the United States Government. Neither the United States Government nor any agency thereof, nor any of their employees, makes any warranty, express or implied, or assumes any legal liability or responsibility for the accuracy. completeness, or usefulness of any information, apparatus, product, or process disclosed, or represents that its use would not infringe privately owned rights. Reference herein to any specific commercial product, process, or service by trade name, trademark, manufacturer, or otherwise does not necessarily constitute or imply its endorsement, recommendation, or favoring by the United States Government or any agency thereof. The views and opinions of authors expressed herein do not necessarily state or reflect those of the United States Government or any agency thereof.

This report has been reproduced directly from the best available copy.

Available to DOE and DOE contractors from the Office of Scientific and Technical Information, P. O. Box 62, Oak Ridge, TN 37831; prices available from (615) $576-8401$.

Available to the public from the National Technical Information Service, U. S. Department of Commerce, 5285 Port Royal Rd., Springfield, VA 22161 


\section{DISCLAIMER}

Portions of this document may be illegible in electronic image products. Images are produced from the best available original document. 
WSRC-TR-95-0050

RAPID ASSESSMENT OF SOIL AND GROUNDWATER TRITIUM BY VEGETATION SAMPLING (U)

Charles E. Murphy Jr.

February 6, 1995

Westinghouse Savannah River Company

Savannah River Site

Aiken, SC 29808 


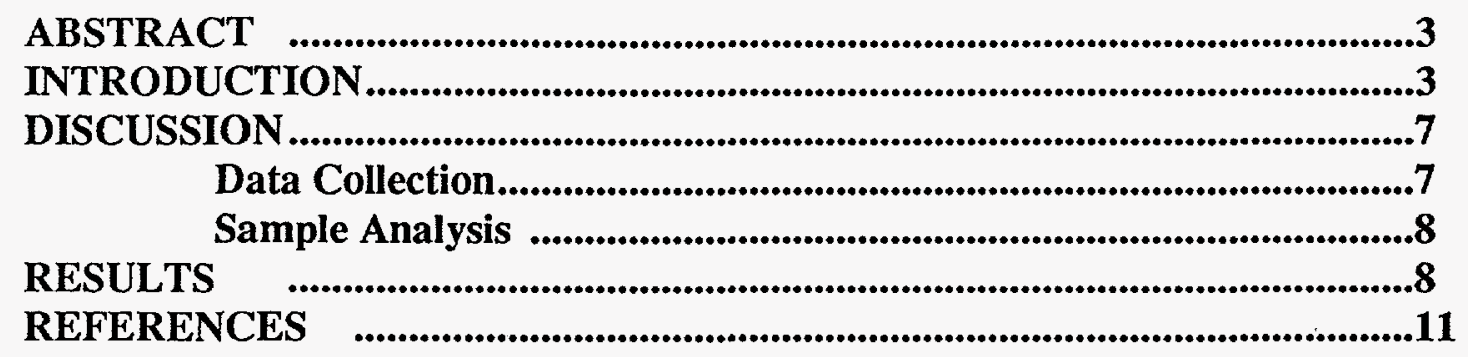


1. Well Water Tritium Contamination below the Southeast Corner of the Solid Waste Disposal Area..............................................................................5

2. .Location of Branch of Four-Mile Branch and Tritium Outcrop Area........................ 6

3. Contours of Tritium Concentration in Water Collected from Trees in the February of 1994.................................................................................................9

4. Contours of Tritium Concentration in Water Collected from Trees in the August of 1994. 9

5. Comparison of Two Samples Taken 25 Days

Apart from the Same Sample Bags ................................................................. 10 


\title{
Rapid Assessment of Soil and Groundwater Tritium by Vegetation Sampling
}

\author{
By Charles E. Murphy Jr. \\ Westinghouse Savannah River Company \\ Savannah River Site \\ Aiken, SC 29808
}

\begin{abstract}
A rapid and relatively inexpensive technique for defining the extent of groundwater contamination by tritium has been investigated. The technique uses existing vegetation to sample the groundwater. Water taken up by deep rooted trees is collected by enclosing tree branches in clear plastic bags. Water evaporated from the leaves condenses on the inner surface of the bag. The water is removed from the bag with a syringe. The bags can be sampled many times. Tritium in the water is detected by liquid scintillation counting. The water collected in the bags has no color and counts as well as distilled water reference samples. The technique was used in an area of known tritium contamination and proved to be useful in defining the extent of tritium contamination.
\end{abstract}

\section{INTRODUCTION}

Contamination of ground water has become one of the most expensive and difficult aspects of remediation of waste burial sites and other instances of surface soil contamination reaching the ground water. Sampling ground water to determine the extent of contamination requires drilling to the contaminated ground water and pumping samples to the surface. Even with recent improvements in groundwater sampling technology, this is a very expensive and time consuming procedure. Therefore, any technology which will replace drilling or even roughly delineate the extent of contamination, allowing a decrease in the number of wells, can improve the cost effectiveness of remediating sites which have ground water contamination.
The content of trace minerals and unmetabolized contaminants in plant tissue reflects the concentration in the environment (Adriano 1986). The minerals and other contaminants which are found in vegetation can enter by gas absorption from the atmosphere, absorption of fallout on plant surfaces, or absorption by the plant roots. Plant roots can actively discriminate between compounds, allowing some to be passively carried with the water extracted from the soil, and others to be concentrated or excluded (Epstein 1972). The discrimination by the roots and the sensitivity of available analytical techniques determine the suitability of plants to monitor contaminant levels in their environment. 
Analysis of vegetation has been used for exploration of deposits of minerals with commercial value (Brooks 1972). Vegetation analysis has also been used to monitor extent and transport of ground water contamination (Vroblesky 1990).

Tritium was used to trace contaminated ground water as early as 1960 (Horton and Ross 1960). Woods and O'Neil (1965) used tritium to determine the ecological significance of water transport to trees from different soil depths. Kalisz (1988) were the first to use this technique to explore the extent of tritium contamination at a nuclear waste burial ground. The objective of this study is to further develop these techniques to provide a rapid, inexpensive method to delineate the extent of ground water contamination in the vicinity of waste sites at the Savannah River Site.

An area near the SRS Solid Waste Disposal Facility (SWDF) was chosen for study. The extent of ground water contamination has been measured and documented (Murphy et al. 1993, Looney et al. 1993). This provides an opportunity to evaluate the methods on a site with supporting data.

The SWDF has been used to store all radioactive solid waste processed at SRS, as well as periodic shipments from other DOE facilities. It is estimated that between 1952 and 19914.5 million curies of tritium were interred at the SWDF (1.5 million curies decay corrected to 1991). .

The primary forms of tritiumcontaining waste in the SWDF are the waste crucibles from the tritium extraction process, other process vessels, and the job control waste containing tritium. The waste crucibles are steel cylinders containing lithium/aluminum alloy and residual tritium.

Operations shifted from open trench burial in the early years of operation to "engineered low-level trenches," and finally to crucibles sealed at each end with an epoxy plug. As a result of the improvement in the containment of tritium over time, the highest concentrations and fluxes of tritium from the waste are in the ground water beneath the oldest part of the SWDF (facility 643-E).

In 1970 a network of wells was installed below the southwest corner of the SWDF to observe the tritium transport from three crucible clusters (two crucibles each) buried in 1957. The results (figure 1) indicated that the tritium had formed a plume in the ground water that was traveling south in the general direction of a surface drainage in this area. In 1979 tritium from the SWDF was detected in the surface stream (a small tributary of Fourmile Branch) draining from this area (Albenesius and Fenimore 1979). An engineering project was begun in 1980 to cover the outcrop area providing tritium to the stream to lengthen the flow path of tritium to the surface. The objective of the project was to increase the time before release to allow for greater decay of tritium before it entered the surface environment. Figure 2 shows the topography of the area and the engineered stream bed and filled outcrop area as it now exists. 
Monitoring in the stream since 1982 indicates a relatively constant discharge of tritium, ranging from 3,600 to 10,500 curies with a mean of 5,500 curies (Looney et al. 1993). This is consistent with calculations which suggest that the buried tritium sources are large relative to releases and will produce fairly constant elevated release for periods of the order of 20-100 years (Stone and Christensen 1983).

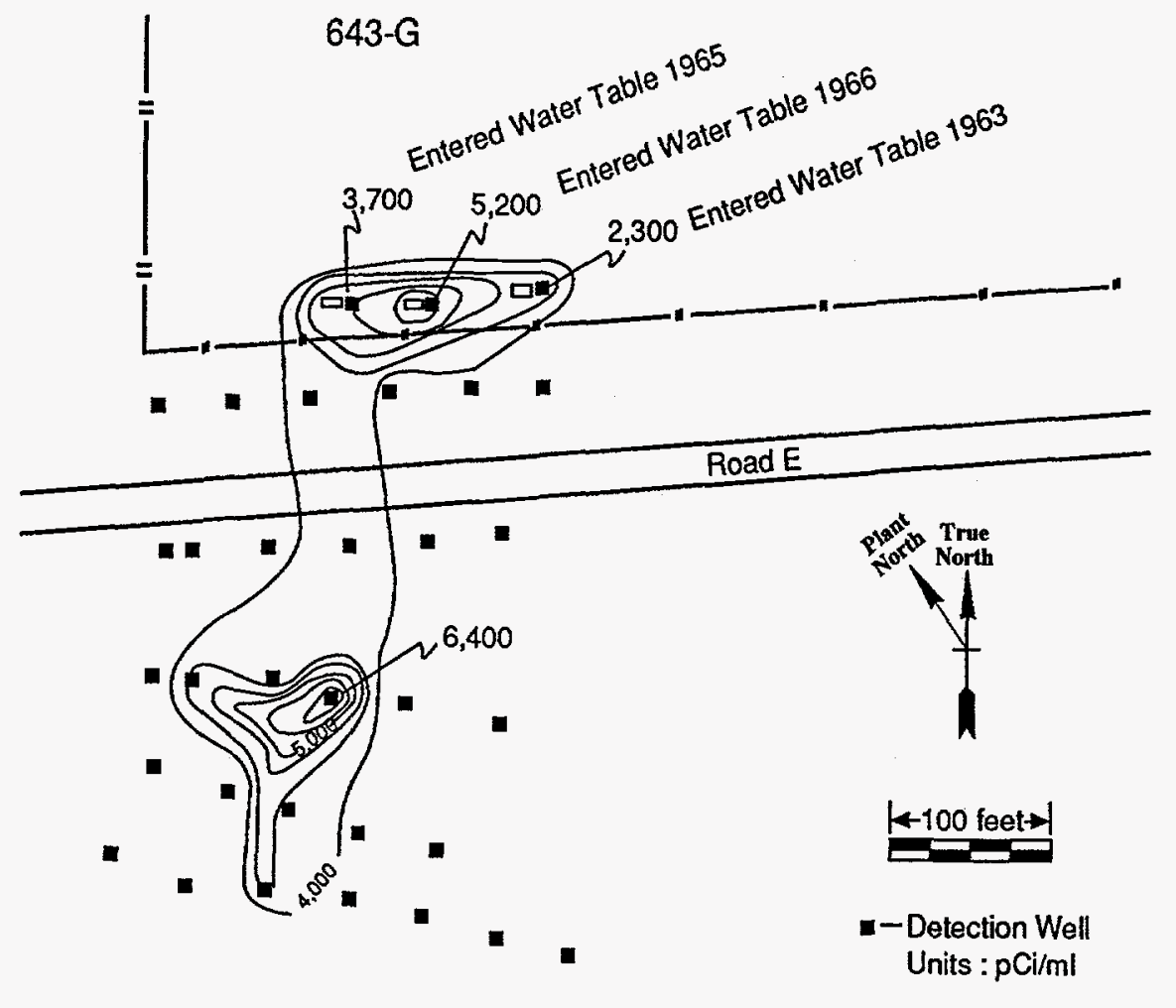

M93X0269.08.All

Figure 1. Well Water Tritium Contamination below the Southeast Corner of the Solid Waste Disposal Area. 


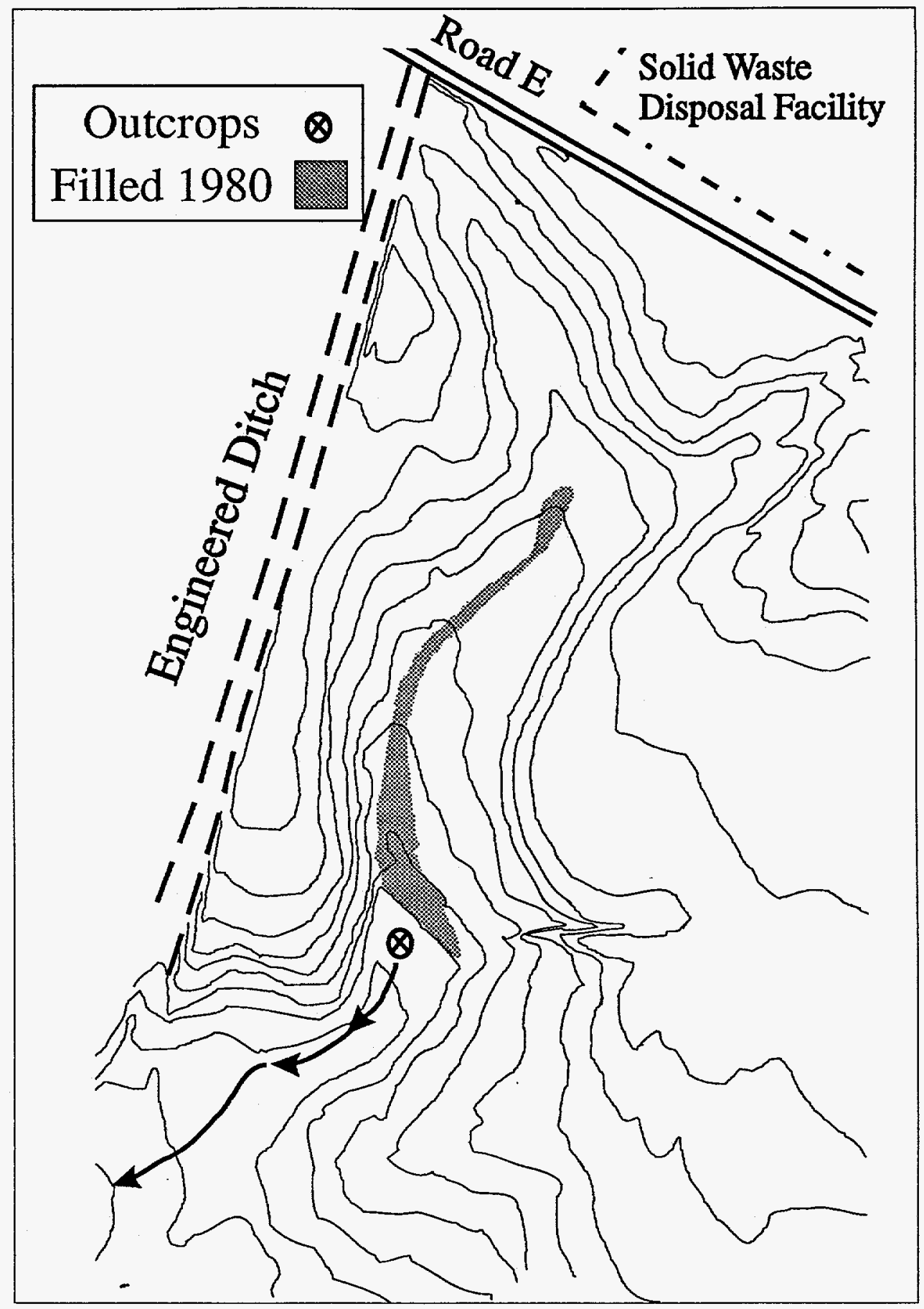

Figure 2. Location of Branch of Fourmile Branch and Tritium Outcrop Area. 


\section{DISCUSSION}

\section{Sample Collection}

Water was collected from the trees using the plastic bag method described in Woods and O'Neil (1965). A single branch or group of small branches were put into a clear polyethylene bag. The bag was sealed against the branch with plastic tape. The sealed bag was left in place from two days to one week. At the end of this period, water had condensed on the plastic bag. The bag was shaken to cause the condensate to run down the surface of the bag and collect in the lower corner of the bag. This water was removed from the bag with a syringe. The hole produced by puncturing the bag with the syringe was sealed with plastic tape and could be resampled later.

The collection of water on the surface of the bag is driven by the difference in temperature between the leaves in the bag and the surface of the bag. The leaves are heated by solar radiation which penetrates the clear bag. In full sunlight, the leaf temperature can be as high as $25^{\circ} \mathrm{F}$ above the air outside the bag. The air inside the bag becomes saturated with water vapor at approximately the temperature of the leaves. When the saturated air reaches the plastic bag, which is at a lower temperature than the leaves, water condenses on the surface.

As first noted by Raney and Vaadia (1965), the tritiated water concentration in leaves is generally lower than that in the soil or the conducting tissue of the vegetation. This is caused by the larger gradient for tritiated water vapor, which has a very low concentration in the atmosphere outside the leaf, than the gradient for water vapor which normally has concentrations that are one-quarter or more than saturation for relative humidities greater than $25 \%$. However, this should not be true for leaves enclosed in a plastic bag. In this case the water in the atmosphere of should approach saturation with water vapor and equilibrium the tritiated water vapor in the air, and therefore at equilibrium with the condensate collected on the inside of the bag.

The trees were sampled at two times of the year. A winter sampling was done between 15-18 February 1994. Four transects of five location were installed on February 15th. The transects were run approximately east to west across the main drainage of the area from a location approximately 100 meters below Road E to the confluence of the drainage with the main branch leading to Fourmile Branch. Water was collected from the bags on February 17th. An additional transect was run on February 17th and sampled on February 21st. At this time of year sampling was limited to evergreen species, primarily pine (Pinus taeda L), holly (Ilex opaca Ait.), and oaks (primarily Quercus laurifolia Michx.). The weather was clear when the bags were put in place with temperature between $32^{\circ}$ and $55^{\circ} \mathrm{F}$. All bags yielded more than $10 \mathrm{~mL}$ of water.

The second sample collection was taken between 22-29 August 1994. The same transects were sampled with the addition of a transect 30 meters from and 
parallel to Road E. The bags were installed on August 22nd and sampled on August 23rd. The water collected in the bags on August 23rd was less than that needed for analysis $(10 \mathrm{~mL})$. The weather during this collection period was overcast, hot $74-95^{\circ} \mathrm{F}$, and humid. In addition, the canopy was much denser because of the additional leaves on the deciduous trees. A second collection of water was made on August 29th. More than enough water was found at this time.

Where possible, deciduous trees were sampled during August. Species included hickory (Carya sp), sweetgum (Liquidambar styraciflua L.), blackgum (Nyssa sylvatica L.), tuliptree (Liriodendron tulipifera L.), holly (Ilex opaca Ait.), oaks (Quercus sp.), and pine (Pinus taeda L.).

The bagged branches appeared to survive in the bags for surprisingly long periods. Some of the bags installed in February contained living branches in August despite the fact that they had collected several liters of water and were bent severely by the weight. The transects run in August were sampled on September 29th and all appeared to have living branches and had collected large amounts of water.

Installation of the transects took about four hours. Sampling took another four hours. Water removed from the plastic bags was transferred to glass vials in the field. The vials were transported to a laboratory for tritium analysis.

\section{Sample Analysis}

The water brought in from the field appear very clear. In some instances small insects and other debris was collected with the water. In this case the debris was allowed to settle to the bottom of the vials before water was removed for analysis.

Liquid scintillation counting (Packard Tri-Carb, Model 2000) was used for tritium analysis. $5 \mathrm{~mL}$ of water was pipetted from the glass storage vials into plastic counting vials containing $17 \mathrm{~mL}$ of liquid scintillation cocktail (Packard Gold Standard). The vials were counted for 5 minutes. Counting statistics based on the shape of the spectrum were the same as those of distilled water standards. The distilled water standards used for calibrating the instrument are traceable to NIST.

\section{RESULTS}

Figures 3 and 4 summarize the results of the tritium measurements. The winter samples show elevated tritium in tree water in those locations that are below the area filled in 1980 (figure 2) and in the flood plain of the small branch draining the area. Trees on the hillside above the flood plain do not show elevated tritium.

The lack of tritium in the hillside trees does not necessarily insure that the ground water tritium plume is confined to the flood plain. It is possible that the trees on the high ground do not have 


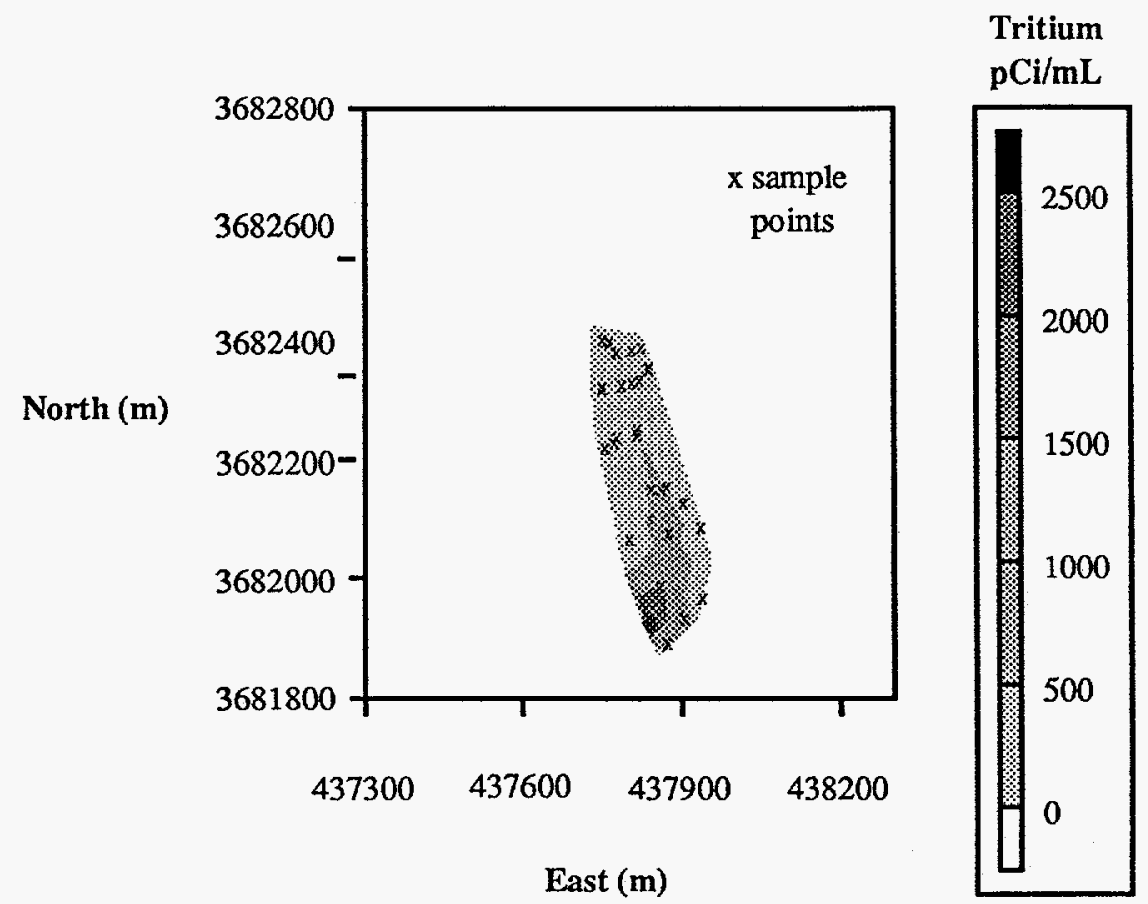

Figure 3. Contours of Tritium Concentration in Water Collected from Trees in the February of 1994.

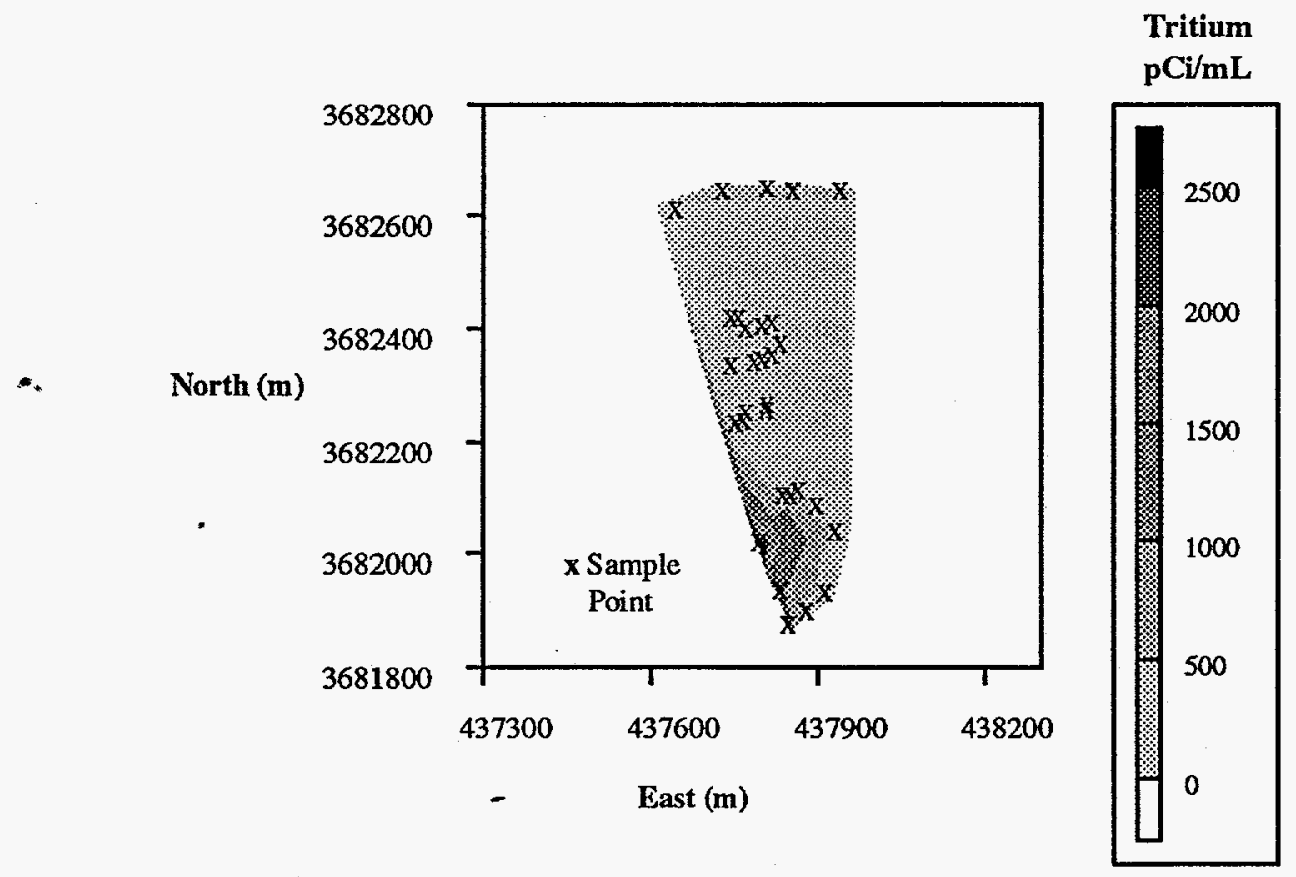

Figure 4. Contours of Tritium Concentration in Water Collected from Trees in the August of 1994. 
roots reaching into the contaminated ground water. However, the topography of this area (shown in figure 1) does suggest that the plume may be restricted to a narrow width as.

The results of the summer sampling is very similar to those of the winter sampling. The additional trees sampled along Road E do not show elevated tritium. They were added to the samples because they are older trees that are not growing on the fill from the 1980 engineering project. However, they are at much higher elevation than the filled area and like the trees growing on the slopes of the drainage above the flood plain they may not be deeply enough rooted to sample the ground water.

The tree located at the northwest end of the transect near Road $E$ is an exception. This tree does show a small elevation in tritium concentration. It is a large oak tree which is likely to have an extensive root system. In addition the elevation at this location is a little lower than that of the other trees on this transect. It is possible that this tree has reached the ground water and tapped the edge of the plume.

Figure 5. shows the results of the 23 September water collection compared to the 29 August collection from the same bags. In general, the results are very similar. However, some bags show a significant dilution between sampling. It is likely that this is caused by entrance of rain into the bags. There were several rains between the sampling days and the accumulation of water in the bags bends the branches so that water runs down the branch towards the bag on the branch end.

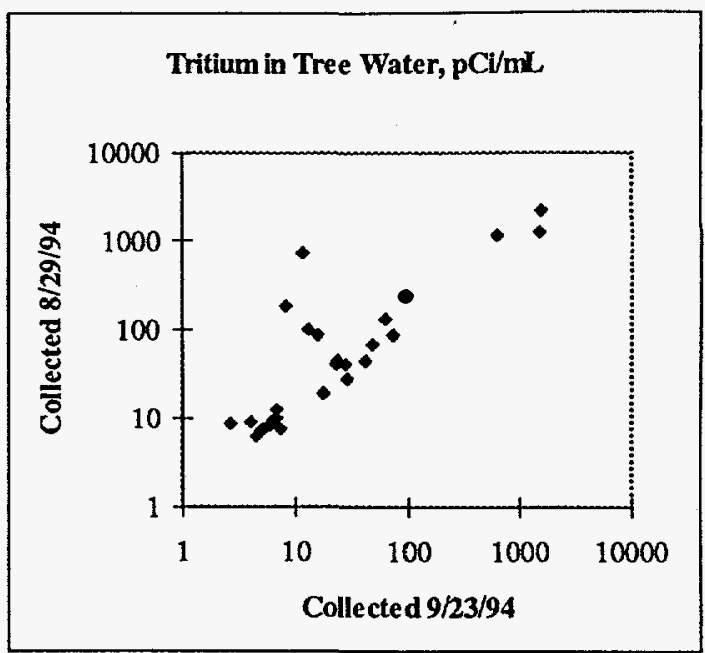

Figure 5. Comparison of Two Samples Taken 25 Days Apart from the Same Sample Bags

This study suggests that trees can be used to sample ground water where the ground water is not too deep or below a soil strata which is difficult for roots to penetrate. The trees did not appear to be able to sample the ground water at the upper end of the basin where the ground water was greater 20 feet below the surface or below the engineered soil cap which was used to cover an area of outcrop.

On the other hand, the trees do show the pattern of tritium in the ground water on the flood plain at the south end of the drainage. The extent of the spread near the confluence of the two branches draining the area was not anticipated. Thus this technique did prove useful in defining areas of contamination that were not expected from measurements made with the existing well network. 


\section{References}

1. Adriano, D.C. Trace Elements in the Terrestrial Environment. SpringerVerlang, New York, 533 p. (1986).

2. Albenesius and, E.L. and J.W. Fenimore. Tritium Migration from the Burial Ground to Four Mile Creek Reappraisal of Flow Paths and Travel Times, DPST-79-265, E.I. du Pont de Nemours and Co., Savannah River Laboratory, Aiken, S.C. (1979).

3. Brooks, R.R. Geobotany and Biogeochemistry in Mineral Exploration. Harper and Row, New York, 290 pp. (1972)

4. Epstein, E. Mineral Nutrition of Plants: Principles and Perspectives. John Wiley and Sons, New York, 412p. (1972).

5. Horton, J.H. and D.I. Ross. Use of Tritium from Spent Uranium Fuel Elements as a Ground-Water Tracer. Soil Sci. Soc. Amer. 90, p 267 (1960)

6. Kalisz, P.J. Trees as Monitors of Tritium in Soil Water. J. Environ. Qual. 17, p. 62 (1988)

7. Looney, B.B., J.S. Haselow, C.M. Lewis, M.K. Harris, D.E. Wyatt, and C.S. Hetrick. Projected Tritium Releases from $F$ \& H Area Seepage Basins and the Solid Waste Disposal Facilities to Fourmile Branch, WSRC-RP-93-459, Westinghouse Savannah River Company, Aiken, S.C. 20 pp.
8. Murphy, C.E., Jr., W.H. Carlton, L.R. Bauer, D.W. Hayes, W.L. Marter, C.C. Seigler, R.L. Nichols, R.N. Strom, B.R. del Carmen, D.M. Hamby, D.D. Hoel, and D.E. Stephenson. Assessment of Tritium in the Savannah River Site Environment. WSRC-RP-93-214. Westinghouse Savannah River Company, Aiken, SC, (1993)

9. Raney, F. and Y. Vaadia. Movement and Distribution of HTO in Tissue Water and Vapor Transpired by Shoots of Helianthus and Nicotiana. Plant Physiol. 90, p. 383 (1965).

10. Stone, J.A. and E.J. Christensen. Technical Summary of Groundwater Protection at Savannah River Plant: Vol II, Radioactive Wastes, DPST-83829 , E.I. du Pont de Nemours and Co., Savannah River Laboratory, Aiken, S.C. (1983)

11. Vroblesky, D.A. and T.M. Yanosky. Use of Tree-Ring Chemistry to Document Historical Contamination Events. Ground Water 28, p. 677 (1990)

12. Woods, F.W. and D. O'Neil. Tritiated Water as a Tool for Ecological Field Studies. Science 147, p. 148 (1965) 